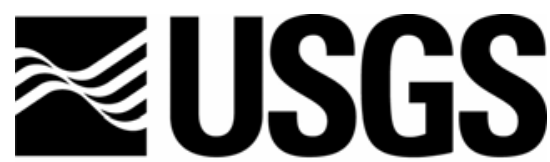

science for a changing world

\title{
Methods for the Emergency Assessment of Debris-Flow Hazards from Basins Burned by the Fires of 2007, Southern California
}

By Susan H. Cannon, Joseph E. Gartner, and John A. Michael

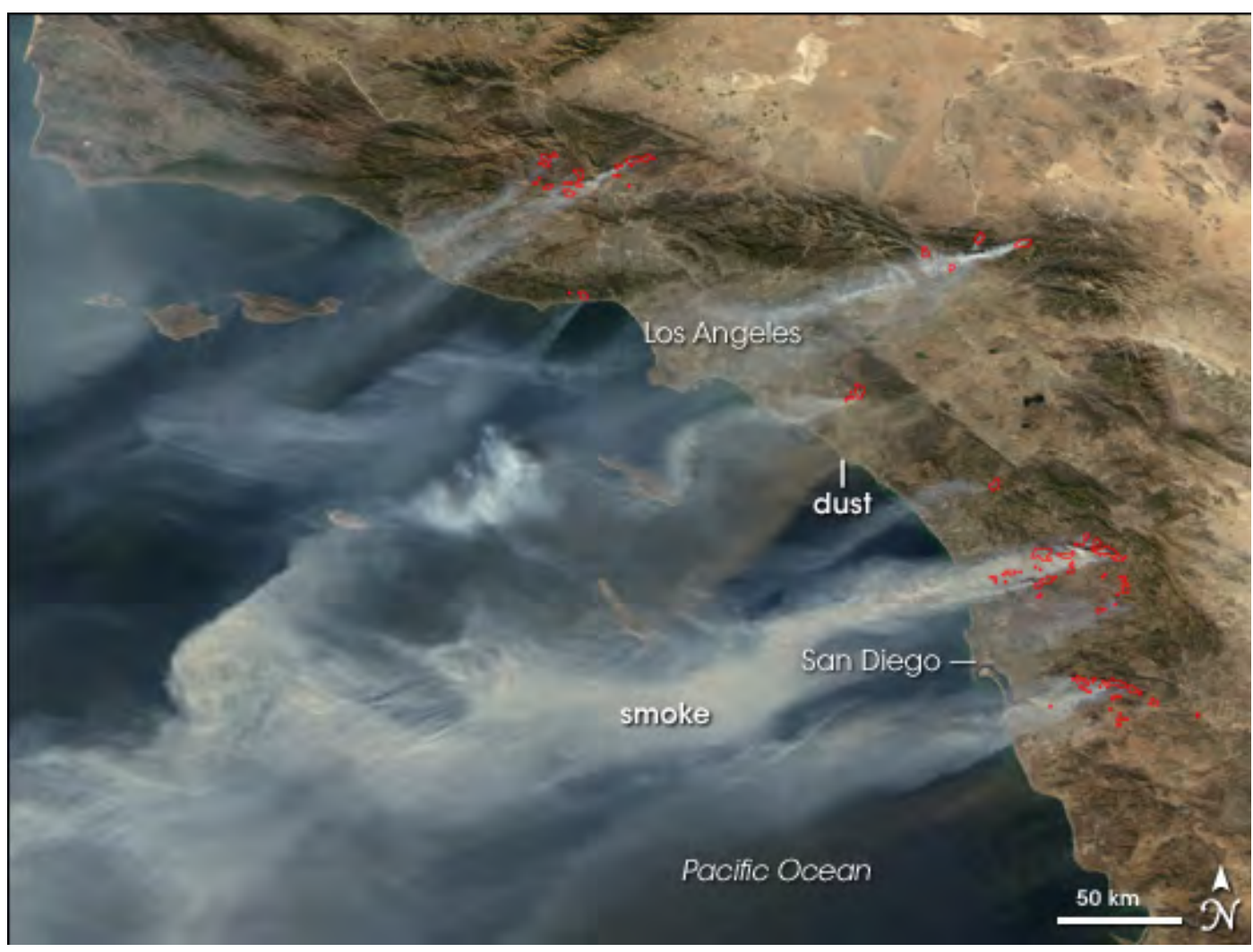

Open-File Report 2007-1384

U.S. Department of the Interior

U.S. Geological Survey 
Frontispiece. Fires burning in southern California at 1:55 p.m. on October 22, 2007. NASA image created using data from the University of Wisconsin's Space Science and Engineering MODIS Direct Broadcast facility. 


\section{U.S. Department of the Interior DIRK KEMPTHORNE, Secretary}

\section{U.S. Geological Survey \\ Mark D. Myers, Director}

\section{U.S. Geological Survey, Reston, Virginia 2007}

For product and ordering information:

World Wide Web: http://www.usgs.gov/pubprod

Telephone: 1-888-ASK-USGS

For more information on the USGS - the Federal source for science about the Earth, its natural and living resources, natural hazards, and the environment:

World Wide Web: http://www.usgs.gov

Telephone: 1-888-ASK-USGS

\section{Suggested citation:}

Cannon, S.H., Gartner, J.E., and Michael, J.A., Methods for the emergency assessment of debris-flow hazards from basins burned by the fires of 2007, southern California: U.S. Geological Survey Open File Report 2007-1384,10 p.

Any use of trade, product, or firm names is for descriptive purposes only and does not imply endorsement by the U.S. Government. This report has not been reviewed for stratigraphic nomenclature.

Although this report is in the public domain, permission must be secured from the individual copyright owners to reproduce any copyrighted material contained within this report. 


\section{Contents}

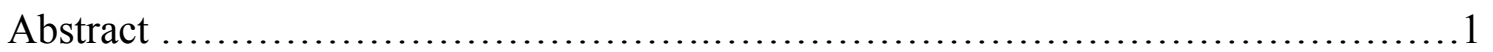

Introduction.............................................................

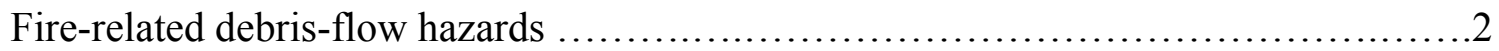

Approach ...................................................................... 4

Debris-flow volume model.............................................. 4

Hazards mapping ....................................................6

Use and limitations of the maps.................................................. 7

References Cited................................................................. 8

\section{Figures}

1. Map showing locations of fires for which hazard maps were generated.....................

\section{Tables}

1. Storm rainfall values used in the assessments.................................6

2. Relative hazard rank assigned to values of debris-flow volume.................... 7 


\title{
Methods for the Emergency Assessment of Debris-flow Hazards from Basins Burned by the Fires of 2007, Southern California
}

\author{
By Susan H. Cannon ${ }^{1}$, Joseph E. Gartner, and John A. Michael
}

\begin{abstract}
This report describes the approach used to assess potential debris-flow hazards from basins burned by the Buckweed, Santiago, Canyon, Poomacha, Ranch, Harris, Witch, Rice, Ammo, Slide, Grass Valley and Cajon Fires of 2007 in southern California. The assessments will be presented as a series of maps showing a relative ranking of the predicted volume of debris flows that can issue from basin outlets in response to a 3-hour duration rainstorm with a 10-year return period. Potential volumes of debris flows are calculated using a multiple-regression model that describes debris-flow volume at a basin outlet as a function of measures of basin gradient, burn extent, and storm rainfall. This assessment provides critical information for issuing basin-specific warnings, locating and designing mitigation measures, and planning of evacuation timing and routes.
\end{abstract}

\section{Introduction}

The objective of this report is to describe the approach used to perform emergency assessments and generate a series of hazard maps that show the potential for debris-flow generation from basins burned by the Buckweed, Santiago, Canyon, Poomacha, Ranch, Harris, Witch, Rice, Ammo, Slide, Grass Valley, and Cajon Fires of 2007 in southern California (Figure 1) for a given rainfall event. The assessments identify the hazards posed by debris flows as a relative ranking of predicted volumes of material that can issue from a basin outlet. Identification of potential debris-flow hazards from burned drainage basins is necessary to issue warnings for specific basins, to make effective and appropriate mitigation decisions, and to aid decisions about evacuation timing and routes.

${ }^{1}$ U.S. Geological Survey, Geologic Hazards Team, Denver Federal Center, MS 966, Denver, CO. 


\section{Fire-Related Debris-Flow Hazards}

Wildfire can have profound effects on a watershed. Consumption of the rainfallintercepting canopy and of the soil-mantling litter and duff, intensive drying of the soil, combustion of soil-binding organic matter, and the enhancement or formation of waterrepellent soils can decrease rainfall infiltration into the soil and significantly increase overland flow and runoff in channels. Removal of obstructions to flow, such as live and downed timber, plant stems, and so forth, by wildfire can enhance the erosive power of overland flow, resulting in accelerated stripping of material from hillslopes. Increased runoff can also erode significant volumes of material from channels. The net result of rainfall on burned basins is often the transport and deposition of large volumes of sediment, both within, and down-channel from burned areas (Cannon and others, 2008; Cannon 2005a).

Debris flows are among the most hazardous consequences of rainfall on burned hillslopes (Cannon 2005b). Debris flows pose a hazard distinct from other sediment-laden flows because of their unique destructive power. They can occur with little warning, exert great impulsive loads on objects in their paths; even small debris flows can strip vegetation, block drainageways, damage structures, and endanger human life. For example, a storm on Christmas Day 2003 triggered debris flows from many of the steep basins burned earlier that fall in the San Bernardino Mountains (Brock and others, 2007). Sixteen people were killed by this event, and billions of dollars were spent for clean up and repairs (Chung and others, 2004). This event clearly illustrates the need for tools to rapidly assess debris-flow hazards immediately after wildfires.

Studies of debris-flow processes throughout the western United States and in southern California demonstrated that the great majority of fire-related debris flows initiate through a process of progressive bulking of storm runoff with sediment eroded from both hillslopes and channels (Cannon, 2000, 2001; Santi and others, 2008).

Although some infiltration-triggered landsliding can occasionally occur in burned basins, and generally in response to prolonged rainfall events, these failures usually contribute a small proportion to the total volume of material transported from basins (Scott, 1971; Cannon and others, 2001). This finding points to the relative importance of runoffdominated, rather than infiltration-dominated, processes of debris-flow initiation in recently burned basins, and indicates that methodologies developed to map landslide potential are generally not appropriate for recently burned areas. 


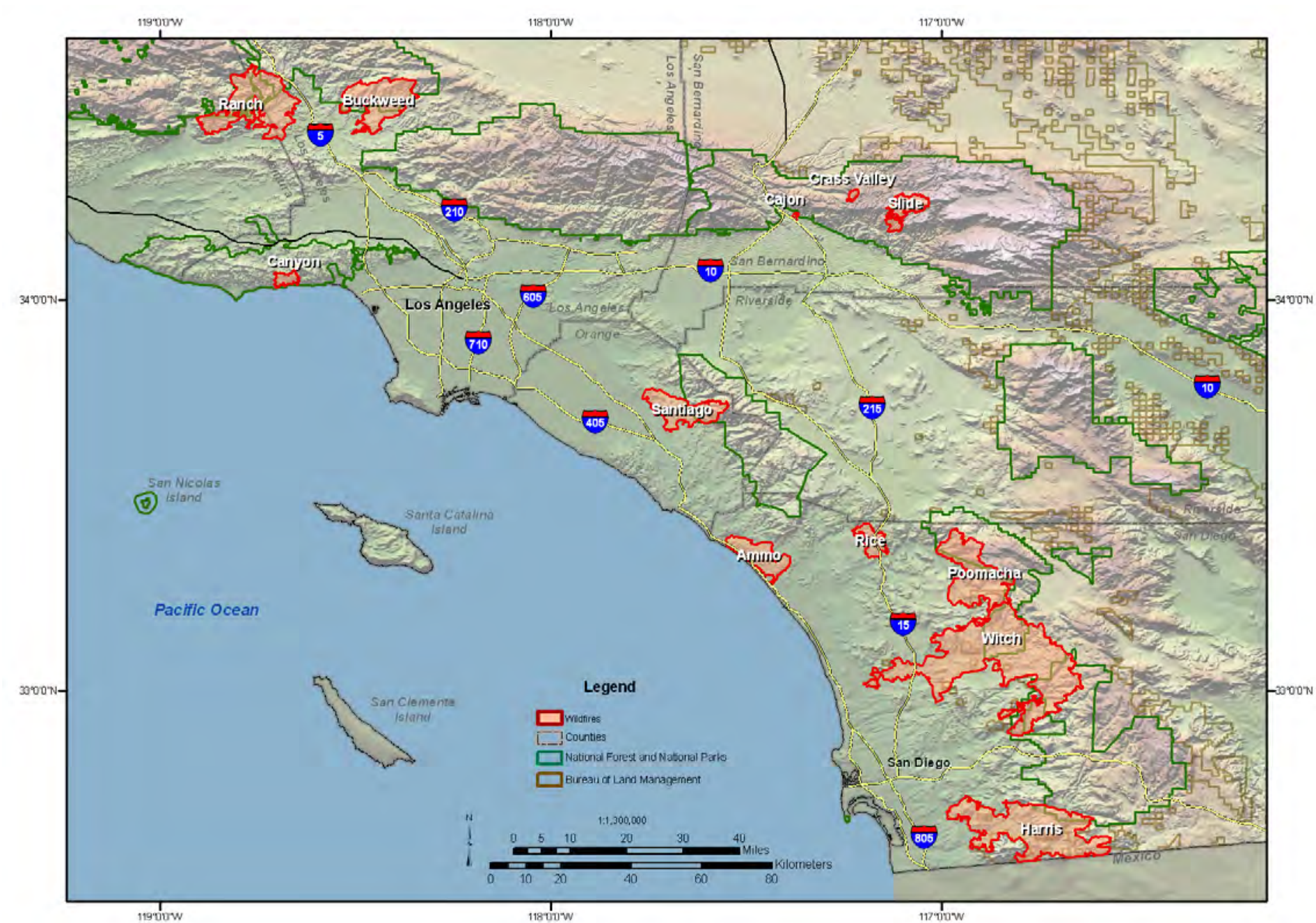

Figure 1. Locations of 2007 fires in Southern California for which debris-flow hazard maps will be generated using methods described in this report. 


\section{Approach}

In a study of the erosional response of recently burned basins throughout the western United States, including southern California, Cannon $(2000,2001)$ found that not all basins produce debris flows; many burned watersheds respond to even heavy rainfall events by sediment-laden flooding, rather than debris flows. However, debris flows represent the most destructive end of the potential runoff response spectrum. Because debris-flow kinematics are significantly distinct from those of streamflow (Iverson, 1997), we have taken the approach of developing predictive relations that are specific to debris flow. Using data collected from 25 recently burned and debris-flow-producing basins throughout southern California, Gartner and others (2008) developed an empirical relation that can be used to estimate debris-flow volumes as a function of the area of the basin burned, storm rainfall conditions, and basin gradients. In this assessment, we use this model to predict the range of potential volumes of material that can be expected at a basin mouth in response to a 10-year recurrence, 3-hour duration rainstorm immediately following wildfire.

\section{Debris-Flow Volume Model}

A multiple-regression model developed using data measured from post-wildfire debris flows is used to define the range of volumes that can potentially be generated from the basins burned by the 2007 fires. The data used in the development of the model consists of measurements from 25 recently burned, and debris-flow-producing, basins located throughout southern California for which estimates of debris-flow volume had been obtained (Gartner and others, 2008). Volumes were determined either through detailed surveys of scoured channels or from measurements of material collected in debris basins.

The multiple regression model provides an estimate of the volume of material expected at the basin outlet as a function of basin gradient, burned extent, and storm rainfall. Because it was not known which measures would best determine debris-flow volume, Gartner and others (2008) evaluated a number of different independent variables in the regression analyses. Eight measures of basin morphology and drainage network were compiled from 30-m or 10-m DEMs, depending on availability. These included:

- Basin area

- Average basin gradient

- Basin relief ratio (the change in elevation between the basin mouth and the top of the longest channel extend to the drainage divide, divided by the length of the channel (Meyer and Wells, 1997))

- Basin ruggedness (maximum change in elevation within a basin divided by the square root of the basin area (Melton, 1965))

- Basin area with slopes greater than or equal to 30 percent

- Basin area with slopes greater than or equal to 50 percent

- Drainage density (the total length of all channels within a basin divided by the basin area, (Horton, 1945))

- Drainage network bifurcation ratio (average ratio of the number of streams of any order to the number of streams of the next highest order (Horton, 1945)) 
Burn severity for each basin was characterized using maps of burn severity generated using the Normalized Burn Ratio (NBR), as determined from Landsat Thematic Mapper data (Key and Benson, 2005). The maps of burn severity reflect changes in biomass from before to immediately after the fire. Gartner and others (2008) evaluated the effects of five measures of burn severity, including:

- Area of the basin area burned at low severity

- Area of the basin area burned at moderate severity

- Area of the basin area burned at high severity

- Area of the basin burned at high and moderate severities

- Total area of the basin burned at all severities

Soil properties for each basin were characterized by samples of burned soils collected in each basin. The soil properties evaluated included:

- Sorting of the burned soil grain-size distribution

- Mean of the soil grain-size distribution

- Median of the soil grain-size distribution

- Skewness of the soil grain-size distribution (from Inman, 1952

The characteristics of storms that affected the monitored basins were determined from tipping-bucket rain gages located within $2 \mathrm{~km}$ of each basin. For each storm to impact a monitored basin, Gartner and others (2008) compiled the:

- Total storm rainfall

- Average storm rainfall intensity

- Peak 10-minute rainfall

- Peak 15-minute rainfall

- Peak 30-minute rainfall

- Peak 60-minute rainfall

Gartner and others (2008) used a series of statistical analyses to determine those factors that most strongly affected debris-flow volumes, and to build the most robust regression model possible. All possible combinations of independent variables were evaluated to determine which combination produced the most effective model. Gartner and others (2008) used a combination of statistical measures including the adjusted $\mathrm{R}^{2}$, the residual standard error, and the standard errors of the coefficients to assess the quality of each model (Helsel and Hirsch, 2002).

Gartner and others (2008) found that the volume of debris flows $\left(V\right.$, in $\left.\mathrm{m}^{3}\right)$ issuing from the outlet of recently-burned basins in southern California can be estimated as a function of the basin area with slopes greater than or equal to 30 percent $\left(A_{30}\right.$, in $\left.\mathrm{km}^{2}\right)$, the area of the basin burned at high and moderate severities $\left(B_{M H}\right.$, in $\left.\mathrm{km}^{2}\right)$, and the total storm rainfall $\left(R_{S}\right.$, in $\left.\mathrm{mm}\right)$. These variables form the basis of a multi-variate statistical model of the form

$$
\ln V=6.6+0.6\left(A_{30}\right)+0.6\left(B_{H M}\right)^{1 / 2}+0.3\left(R_{S}\right)^{1 / 2}
$$

The adjusted $\mathrm{R}^{2}$ of this model (0.90) and residual standard error (0.62), coupled with additional tests of model quality, indicated that the result is the best possible model, 
given the available data. Graphical analyses indicate no apparent correlation between average basin gradient and burned area. Model validation using a dataset not used in the development of the regression model revealed that measured volumes were within two standard errors of the predicted volumes. We used this model in a Geographical Information System (GIS) to estimate the median volume of a post-fire debris flow at the outlets of individual drainage basins in the 2007 burned areas in response to a single storm event.

\section{Hazards Mapping}

Potential debris-flow volumes were determined for basins burned by the Buckweed, Santiago, Canyon, Poomacha, Ranch, Harris, Witch, Rice, Ammo, Slide, Grass Valley and Cajon Fires of 2007 (fig. 1). Basins were delineated for the assessment by starting with several specific locations identified by the BAER (Burned Area Emergency Response) teams and emergency managers as locations of concern in their post-fire assessments. Outlets above those specific locations, as well as throughout the burned areas, were identified and the basins above those locations delineated. The delineated basins range in area between 0.02 and $30 \mathrm{~km}^{2}$, reflecting the sizes of the basins used in the model development.

For each basin, we compiled values for each of the input variables for the model. Measures of basin gradient were obtained from 10-m DEMs. The basin areas burned at different severities were characterized from the burn severity mapping, as described above.

The volume of potential debris flows were calculated in response to a 10-year recurrence, 3-hour-duration storm for basins within the fires listed in table 1. Storm rainfall values used in the models (table 1) were obtained from Hershfield (1963). Although there is considerably more variability in storm-rainfall characteristics across burned areas than represented by these single values, we used them as representative of storm rainfall likely to impact the recently burned areas in the near future.

Table 1. Storm rainfall values used in assessments (from Hershfield, 1963).

Fire Name Storm Total for the 10-year
recurrence, 3-hour duration storm

\begin{tabular}{cc}
\hline Santiago, Ammo, Rice, Harris & 1.75 inches $(44.45 \mathrm{~mm})$ \\
Witch, Poomacha, Ranch, & 2.25 inches $(57.15 \mathrm{~mm})$ \\
Buckweed, Canyon & \\
Cajon & 3.25 inches $(82.55 \mathrm{~mm})$ \\
\hline Grass Valley, Slide & 3.50 inches $(88.90 \mathrm{~mm})$ \\
\hline
\end{tabular}

To show this information in map form, the calculated values of debris-flow volume for each basin will be proportioned into relative rankings (table 2): 
Table 2. Relative rankings assigned to predicted values of debris flow volume.

\begin{tabular}{lc}
\hline $\begin{array}{l}\text { Calculated } \\
\text { Volume } \\
\left(\mathbf{m}^{\mathbf{3}}\right)\end{array}$ & $\begin{array}{c}\text { Volume } \\
\text { Ranking } \\
\text { Value }\end{array}$ \\
\hline $0-1,000 \mathrm{~m}^{3}$ & 1 \\
$1,001-10,000 \mathrm{~m}^{3}$ & 2 \\
$10,001-100,000 \mathrm{~m}^{3}$ & 3 \\
\hline$>100,000 \mathrm{~m}^{3}$ & 4 \\
\hline
\end{tabular}

\section{Use and Limitations of the Maps}

The maps that will be generated using the approach described above will show estimates of the relative hazards posed by debris flows that may issue from the outlets of basins burned by the Buckweed, Santiago, Canyon, Poomacha, Ranch, Harris, Witch, Rice, Ammo, Slide, Grass Valley and Cajon Fires of 2007 in southern California in response to a 10-year recurrence, 3-hour duration rainstorm. The maps will identify the range of potential debris flow median volumes that can issue from individual basin outlets. This information can be used to issue warning for specific locations, to prioritize mitigation efforts, to aid in the design of mitigation structures, and to guide decisions for evacuation, shelter, and escape routes in the event that storms of similar magnitude to those evaluated here are forecast for the area.

In addition to the potential dangers within these basins, areas downstream from the basin outlets are also at risk. In some of these areas, homes were destroyed by the fires, and workers and residents may be busy cleaning and rebuilding sites. These people may be at high risk for impact by debris flow during rainfall events. In addition, there is a great possibility of culverts plugging or being overwhelmed, and of roads washing out. Such events can strand motorists for long periods of time. In some cases, channels cross roads on blind curves where motorists could abruptly encounter debris-flow deposits on the road.

The potential for debris-flow activity decreases with time because revegetation stabilizes hillslopes. A compilation of information on post-fire runoff events reported in the literature from throughout the western United States indicates that under normal rainfall conditions most debris-flow activity occurs within about 2 years following a fire (Gartner and others 2005). If dry conditions prevent sufficient re-growth of vegetation, this recovery period will be longer. We thus conservatively expect that the maps presented here may be applicable for approximately 3 years after the fires for the storm conditions considered here. Furthermore, the assessments presented here are specific to post-fire debris flows; significant hazards from flash flooding can remain for many years after a fire.

Lastly, the parameters included in the models are considered to be possible firstorder effects that can be rapidly evaluated immediately after a fire. Other conditions than those used in the model may also affect debris-flow production from recently burned 
basins in southern California. For example, an abundance of dry-ravel material in a specific channel may affect volumes, and the frequently occurring fire-flood sequence that characterizes southern California basins may similarly limit material available for incorporation into debris flows (Spittler, 1995). However, data necessary to evaluate these effects are not currently available.

\section{References Cited}

Brock, R. J., Cannon, S.H., Gartner, J.E. Santi, P.M., Higgins, J.D., and Bernard, D.R., 2007, An ordinary storm with an extraordinary response: Mapping the 2003 Old and Grand Prix Fire areas in southern California: Geological Society of America Abstracts with Programs, v. 39, No. 6, p. 180.

Cannon, S.H., 2000, Debris-flow response of southern California watersheds recently burned by wildfire, in Wieczorek, G.F., and Naeser, N.D, eds., Debris-Flow Hazards Mitigation - Mechanics, prediction, and assessment, Proceedings of the Second International Conference on Debris-Flow Hazards Mitigation, Taipei, Taiwan, 16-18 August 2000: A.A. Balkema, Rotterdam, p. 45-52.

Cannon, S.H., 2001, Debris-flow generation from recently burned watersheds: Environmental and Engineering Geoscience, v. 7, p. 321-341.

Cannon, S.H., 2005a, Southern California—Wildfires and debris flows: U.S. Geological Survey Fact Sheet 2005-3106. http//pubs.usgs.gov/fs/2005/3106.

Cannon, S.H., 2005b, A NOAA-USGS demonstration flash-flood and debris-flow earlywarning system: U.S. Geological Survey Fact Sheet 2005-3104. http://pubs.usgs.gov/fs/2005/3104/.

Cannon, S.H. and Gartner, J.E., 2005, Wildfire-related debris flow from a hazards perspective, chapter 15, in Hungr, Oldrich and Jacob, Mathias, eds., Debris-flow hazards and related phenomena, Springer-Praxis Books in Geophysical Sciences, p. 321-344.

Cannon, S.H., Gartner, J.E., Wilson, R.C., and Laber, J.L., 2008, Storm rainfall conditions for floods and debris flows from recently burned areas in southwestern Colorado and southern California: Geomorphology, doi:10.1019/j.geomorph.2008.03.019.

Cannon, S.H., Kirkham, R.M. and Parise, Mario, 2001, Wildfire-related debris-flow initiation processes, Storm King Mountain, Colorado: Geomorphology, v. 39, p. 171188.

Chong, J., Renaud, J., Ailsworth, E., 2004, Flash floods wash away lives, dreams: Los Angeles Times, Jan 3, 2004, p. B.1. 
Gartner, J.E., Cannon, S.H., Bigio, E.R., Davis, N.K., Parrett, C., Pierce, K.L., Rupert, M.G., Thurston, B.L., Trebish, M.J., Garcia, S.P., and Rea, A.H., 2005, Compilation of data relating to the erosive response of 606 recently burned basins in the western U.S.: U.S. Geological Survey Open-File Report 2005-1218.

Gartner, J.E., Cannon, S.H., Santi, P.M., deWolf, V.G., 2008, Empirical models to predict debris flow volumes generated from recently burned basins in the western U.S.: Geomorphology, doi:10.1016/j.geomorph.2008.02.033.

Helsel, D.R., and Hirsch, R.M., 2002, Statistical methods in water resources, Studies in Environmental Science 49: Elsevier, Amsterdam, 489 p.

Hershfield, D.M., 1963, Rainfall frequency atlas of the United States for durations from 30 minutes to 24 hours and return periods from 1 to 100 years: Technical Paper No 40, U.S. Department of Commerce, Weather Bureau, 61 p.

Horton, R.E., 1945, Erosional development of streams and their drainage basins Hydrological approach to quantitative geomorphology: Geological Society of America, Bulletin No. 56, p. 275-370.

Inman, D.L., 1952, Measures for describing the size distribution of sediments: Journal of Sedimentary Petrology, v. 22, p. 125-145.

Iverson, R.M., 1997, The physics of debris flow, Reviews in Geophysics, v. 35, p. 245296.

Key, C.H., and Benson, N.C., 2005, Landscape assessment-Remote sensing of severity, the Normalized Burn Ratio, in D.C. Lutes and others, eds., FIREMON- Fire Effects Monitoring and Inventory System, Ogden Utah, USDA Forest Service Rocky Mountain Research Station, General Technical Report, RMS-GTR-164-CD:LA1-LA51.

Melton, M.A., 1965, The geomorphic and paleoclimatic significance of alluvial deposits in southern Arizona: Journal of Geology, v. 73, p. 1-38.

Meyer, G.A., and Wells, S.G., 1997, Fire-related sedimentation events on alluvial fans, Yellowstone National Park, U.S.A.: Journal of Sedimentary Research, v. 67, no. 5, p. 776-791.

Santi, P.M., deWolf, V.G., Higgins, J.E., Cannon, S.H., Gartner, J.E., 2008, Sources of debris flow material in burned areas: Geomorphology, doi:10.1016/j.geomorph.2008.02.022.

Scott, K.M., 1971, Origin and sedimentology of 1969 debris flows near Glendora, California: U.S. Geological Survey Professional Paper 750-C, p. C242-C247. 
Spittler, T.E., 1995, Fire and debris flow potential of winter storms, in Keely, J.E., and Scott, T., eds., Brushfires in California wildlands - Ecology and resource management: International Association of Wildland Fire, Fairfield, WA. 